\title{
PENGGUNAAN BAHASA INDONESIA DALAM PENULISAN ARTIKEL ILMIAH
}

\author{
Eti Ramaniyar ${ }^{1}$, Al Ashadi Alimin ${ }^{2}$, Hariyadi $^{3}$ \\ ${ }^{1}$ IKIP PGRI Pontianak \\ ${ }^{21}$ IKIP PGRI Pontianak \\ ${ }^{3}$ IKIP PGRI Pontianak \\ Eramaniyar25@gmail.com
}

\begin{abstract}
Abstrak
Penelitian ini bertujuan untuk mengetahui penggunaan bahasa Indonesia dalam penulisan Artikel Ilmiah pada mahasiswa Program Studi Pendidikan Bahasa dan Sastra Indonesia Angkatan 2017. Penelitian ini merupakan penelitian kualitatif dengan metode deskriptif. Teknik pengumpulan data yang digunakan adalah teknik studi dokumenter. Data dianalisis menggunakan model analisis interaktif. Hasil penelitian menunjukan kesalahan ejaan berupa penulisan kata, pemakaian huruf, tanda baca, dan unsur serapan. Pada sistematika penulisannya banyak ditemukan kesalahan dalam menulis bagian pembuka yaitu judul artikel ditulis terlalu singkat dan kurang informatif, bagian pendahuluan yaitu latar belakang artikel tidak sesuai dengan permasalahan, bagian akhir yaitu simpulan tidak memuat jawaban atas pertanyaan penelitian, serta bagian daftar pustaka yaitu daftar referensi tidak sesuai dan daftar rujukan tidak berurutan sesuai abjad.
\end{abstract}

Kata Kunci : kesalahan ejaan, sistematik penulisan, artikel ilmiah

\begin{abstract}
This study aims to find out the use of Indonesian in the writing of Scientific Articles for students of the Indonesian Language and Literature Education Study Program in 2017. This research is a qualitative research with a descriptive method. The data collection technique used is documentary study techniques. Data were analyzed using interactive analysis models. The results showed spelling errors in the form of word writing, use of letters, punctuation, and absorption elements. While systematic writing found many errors in writing the opening part, namely the title of the article was written too short and less informative, the introduction part of the article background does not match the problem, the final part is the conclusion does not contain answers to research questions, and the bibliography section reference list is not accordingly and the list of references is not sequential in alphabetical order.
\end{abstract}

Keywords: spelling mistakes, systematic writing, scientific articles

\section{PENDAHULUAN}

Penggunaan bahasa Indonesia dalam penulisan artikel ilmiah penting untuk dikuasai oleh mahasiswa. Khususnya mahasiswa Program Studi Pendidikan Bahasa dan Sastra Indonesia ini menjadi bagian yang patut diperhatikan. Penulisan artikel ilmiah ini telah menjadi persoalan serius di kalangan mahasiswa. Di era teknologi dan internet dapat diakses dimana saja membuat mahasiswa menjadi malas untuk menulis artikel ilmiah yang sesuai dengan pemikirannya. Mahasiswa sering kali menulis dengan gaya penulisan yang tidak sesuai dengan 
Pedoman Umum Ejaan Bahasa Indonesia. Hal ini tentu menjadi masalah bagi dosen dan mahasiswa tersebut, karena jika dibiarkan maka selamanya mahasiswa akan melakukan kesalahan tanpa adanya usaha untuk membuat artikel tulis ilmiah yang baik dan benar. Berdasarkan hal tersebut, peneliti mengambil judul penelitian "Analisis Penggunaan Bahasa Indonesia dalam Penulisan Artikel Ilmiah pada Mahasiswa Program Studi Pendidikan Bahasa dan Sastra Indonesia Angkatan 2017"

Penggunaan bahasa Indonesia baku memiliki sifat kemantapan dinamis, yang berupa kaidah dan aturan tetap. Baku atau standar tidak dapat berubah setiap saat. Kaidah pembentukan kata yang memunculkan bentuk perasa dan perumus dengan taat asas harus dapat menghasilkan bentuk perajin dan perusak, bukan pengrajin dan pengrusak. Keharmoniman yang timbul akibat penerapan kaidah itu bukan alasan yang cukup kuat untuk menghalalkan penyimpangan itu. Bahasa mana pun tidak dapat luput dari keharmoniman. Dipihak lain, kemantapan itu tidak kaku, tetapi cukup luwes sehingga kosa kata dan peristilahan serta mengizinkan perkembangan berjenis ragam yang diperlukan di dalam kehidupan modern. Ragam baku yang baru, antara lain, dalam penulisan laporan, karangan ilmiah, undangan, dan percakapan telepon perlu dikembangkan lebih lanjut. Alwi, dkk (2010: 14-16) menyebutkan bahasa baku mendukung empat fungsi, tiga diantaranya bersifat pelambang atau simbolik, sedangkan yang satu lagi bersifat objektif: (1) fungsi pemersatu, (2) fungsi pemberi kekhassan, (3) fungsi pembawa kewibawaan, dan (4) fungsi sebagai kerangka acuan.

Satu diantara penggunaan bahasa indonesia baku adalah ragam ilmiah atau bahasa ilmiah. Bahasa ilmiah biasanya digunakan untuk karangan ilmiah. Adapun ciri-cirinya menurut Chaer (2011: 4) yaitu, 1) bersifat lugas. Artinya, apa yang diutarakan, dikatakan saja secara langsung, apa adanya, tidak berbelit-belit, atau bertele-tele, atau tanpa kalimat yang berbunga-bunga. 2) Mematuhi kaidah-kaidah grmatika. Artinya, kalimat-kalimat dan paragraph-paragraf sesuai dengan kaidahkaidah tata bahasa. 3) Efektivitas kalimat-kalimatnya terpenuhi. Maksudnya, pesan-pesan yang dikandung kalimat-kalimat itu dapat diterima pembaca persis seperti yang diinginkan penulis. 4) Kosa kata yang digunakan, selain kosa kata 
baku, juga sesuai dengan kaidah pemilihan kata (diksi); dan istilah-istilah yang digunakan sesuai dengan bidang ilmu yang ditekuni. 5) kalimat-kalimtanya bebas dari ketaksaan (ambiguity). Maksudnya kalimat-kalimatnya, atau paragrafparagrafnya tidak menimbulkan tafsir ganda. 6) Bebas dari makna kias dan figura bahasa. Artinya kata-kata atau kalimat-kalimat yang digunakan harus bermakna lugas. Misalnya kata buaya dalam ucapan buaya darat adalah bermakna kias; tetapi dalam ucapan buaya yang ada di darat tidak bermakna kias, melainkan bermakna sebenarnya, yang disebut makna leksikal. 7) Mematuhi persyaratan penalaran. Maksudnya, secara semantik kalimat-kalimat bersifat logis dan dapat diterima oleh akal sehat. 8) mematuhi atau menerapkan kaidah-kaidah ejaan yang berlaku. (saat ini adalah Pedoaman Umum Bahasa Indonesia, disingkat PUEBI). Semua ciri itu harus tampak terjalin pada setiap kalimat, setip paragraf atau pada karangan ilmiah itu seutuhnya.

Bahasa Indonesia mengalami perkembangan yang sangat pesat sebagai dampak kemajuan ilmu pengetahuan, teknologi, dan seni. Penggunaannya pun semakin luas dalam berbagai ranah pemakaian, baik secara lisan muapun tulis. Oleh karena itu Pedoman Umum Ejaan Bahasa Indonesia sangat diperlukan sebagai acuan standar penggunaan bahasa Indonesia terutama dalam pemakaian bahasa tulis, secara baik dan benar. Secara garis besar Pedoman Umum Ejaan Bahasa Indonesia memuat empat bab pokok bahasan; 1. Pemakaian huruf, 2. Penulisan kata, 3. Pemakaian tanda baca, 4. Penulisan unsur serapan.

Artikel hasil pemikiran atau kajian pustaka merupakan pemikiran penulis tentang suatu permasalahan. Artikel hasil pemikiran haruslah bersifat provokatif, merangsang pembaca untuk mengkaji isi artikel (Budhiharso, 2009: 77-78). Lebih lanjut dikatakan, artikel hasil pemikiran dikembangkan berdasarkan tulisan dalam artikel yang relevan, hasil-hasil penelitian terdahulu, dan buku teks. Unsur terpenting dari artikel hasil pemikiran adalah pendapat penulis tentang suatu masalah yang dibahas. Penulis menunjukkan hasil pemikiran kritis dan analitis terhadap suatu permasalahan. Jadi, artikel hasil pemikiran bukan sekedar tempelan pemikiran orang lain yang dikutip dalam artikel lain. Artikel hasil pemikiran 
biasanya disajikan dalam format: judul, nama penulis, abstrak, kata kunci, pendahuluan, bagian inti atau pembahasan, penutup, dan daftar pustaka.

Barnawi dan Arifin (2015: 140) menyampaikan bahwa artikel ilmiah karangan nonfiksi yang menjelaskan fenomena sosial dan/atau alam, berdasarkan laporan kegiatan lapangan dan/atau kajian pustaka untuk mencari kebenaran, ditulis sesuai dengan aturan media yang menerbitkannya. Menurut Soeharso (2009: 8-9) menyatakan bahwa artikel ilmiah, sesuai namanya adalah artikel yang memiliki nilai atau memenuhi kaidah (syarat keilmuan). Artinya, artikel ilmiah menggunakan metode ilmiah dalam membahas permasalahan, menyajikan kajian dengan dengan ragam bahasa dan tata tulis ilmiah, dan menggunakan prinsipprinsip keilmuan pada umumnya, seperti obyektif, logis, empiris, sistematis. Fatihudin dan Holisin (2011: 10) menegaskan artikel ilmiah adalah karya tulis yang mengkaji atau membahas suatu topik/masalah dengan mengkuti kaidahkaidah ilmiah. Artikel ilmiah adalah tulisan ilmiah yang akan dimuat di jurnal ilmiah atau jurnal lainnya yang ber-ISSN, terakreditasi, jurnal Nasional, atau bahkan jurnal Internasional.

Barnawi dan Arifin, (2015: 140-141) menjelaskan bahwa artikel ilmiah memiliki ciri-ciri sebagai berikut. 1) Logis, objektif, dan sistematis. Logis berarti artikel ilmiah ditulis dengan dasar yang masuk akal dan dapat diuji kebenarannya. Objektif mengandung makna bahwa artikel ilmiah menyajikan fakta atau data sesuai dengan keadaan yang sebenarnya dan dianalisis secara logis tanpa mengedepankan emosi. Sedangkan sistematis berarti artikel ilmiah disusun secara teratur dan logis sehingga bersifat utuh, menyeluruh, dan terpadu. 2) Singkat, jelas, dan menarik. Ciri singkat mengandung makna bahwa artikel ilmiah ditulis dengan kalimat yang tidak bertele-tele. Ciri jelas mengandung makna bahwa artikel ilmiah mudah dimengerti. Misalnya, tidak menggunakan kata-kata ambigu atau menggunakan kalimat yang berputar-putar. Sementara itu, ciri menarik berarti artikel ilmiah dapat menggugah emosi untuk membaca sampai selesai.

Sejalan dengan apa yang diungkapkan Barnawi dan Arifin, Apandi, (2015: 56) juga menjelaskan beberapa ciri dari artikel ilmiah yaitu, 1) Singkat, padat, jelas, fokus pada suatu topik atau masalah tertentu, 2) Menggunakan bahasa yang 
lugas dan tidak berbelit-belit, 3) Sistematika yang sederhana, 4) Objektif dan proporsional, 5) Tidak mengandung unsur SARA, fitnah, atau kebencian kepada pihak lain.

Penggunaan bahasa Indonesia dalam penulisan artikel ilmiah pada mahasiswa prodi pendidikan bahasa dan sastra Indonesia IKIP PGRI Pontianak merupakan suatu prosedur wajib digunakan oleh peneliti. Dengan adanya analisis kesalahan berbahasa ini diharapkan memberikan banyak keuntungan, khususnya yang berhubungan dengan kegiatan pengajaran bahasa Indonesia Ayudia, dkk (2016).Berdasarkan hal tersebut, peneliti melakukan penelitian pada mahasiswa prodi pendidikan bahasa dan sastra Indonesia dengan mengambil beberapa sampel artikel untuk dianalisis agar diketahui kesalahan berbahasa yang ada dalam artikel ilmiah yang ditulis oleh mahasiswa. Adapun kesalahan yang terdapat pada penulisan artikel mahasiswa diantaranya: kesalahan penggunaan ejaan, penggunaan diksi, penyusunan kalimat serta paragraf. Analisis yang dilakukan guna memperbaiki serta menyempurnakan penulisan artikel pada mahasiswa. Dengan demikian, analisis yang dilakukan sangat diperlukan untuk menyempurnakan penggunaan bahasa Indonesia pada artikel mahasiswa IKIP PGRI Pontianak khususnya prodi pendidikan bahasa dan sastra Indonesia.

\section{METODE}

Bentuk penelitian yang digunakan untuk penelitian ini adalah penelitian kualitatif dengan metode deskriptif. metode deskriptif dianggap tepat untuk menjelaskan fenoma-fenomea kebahasaan yang kompleks seperti penggunaan bahasa. Rancangan penelitian ini digunakan sebagai prosedur untuk mengindetifikasi dan mendeskripsikan penggunaan bahasa Indonesia dalam penulisan karya ilmiah pada Mahasiswa Program Studi Pendidikan Bahasa dan Sastra Indonesia Angkatan 2017.

Sampel penelitian dalam penelitian kualitatif menurut Mahsun (2012: 2930) Pemilihan sebagian dari keseluruhan penutur atau wilayah pakai bahasa yang menjadi objek penelitian sebagai wakil yang memungkinkan untuk membuat generalisasi terhadap populasi. Sampel penutur sebagai bahan sumber bahan penelitian, memberi informasi, dan membantu peneliti dalam tahap penyediaan 
data dalam penelitian kebahasan disebut informan. Berdasarkan pendapat di atas, subjek atau informan dalam penelitian ini melibatkan mahasiswa angkatan 2017 yang saat ini berada di semester III. Penggunaan Teknik studi dokumenter dalam penelitian ini dibantu dengan instrument berupa kartu pencatat data. Penggunaan kartu pencatat data dimaksudkan untuk mencatat data-data yang akan dianalisis untuk mempermudahkan peneliti dalam mengklasifikasikan, mengingat dan memeriksa kembali dalam proses penelitian.

Analisis dalam penelitian kualitatif terdiri dari 3 komponen pokok, Miles dan Huberman dalam Sutopo (2002: 94) terdapat dua model pokok dalam melaksanan analisis di dalam penelitian kualitatif, yaitu (1) model analisis jalinan atau mengalir (flow model of analysis) dan (2) model analisis interaktif. Kedua model tersebut terdiri dari tiga komponen pokok, yaitu: reduksi data, sajian data, dan penarikan simpulan dengan verifikasi.

\section{HASIL DAN PEMBAHASAN}

Dalam hasil penelitian ini, peneliti memaparkan kesalahan ejaan dan sistematika penulisan yang terdapat dalam artikel ilmiah mahasiswa. Peneliti akan memaparkan hasil penelitian berdasarkan masalah yang ada, pertama permasalahan yang berkaitan dengan kesalahan ejaan, sedangkan kedua yang berkaitan dengan kesalahan sistematika penuisan artikel. Uraian berikut mengutip contoh masing-masing kesalahan.

\section{Analisis Kesalahan Ejaan pada Artikel Ilmiah Mahasiswa Program Studi Pendidikan Bahasa dan Sastra Indonesia Angkatan 2017 IKIP PGRI Pontianak}

\section{a. Pemakaian Huruf}

Dalam pemakaian huruf peneliti menemukan kesalahan yang terdapat pada penulisan huruf kapital, beberapa contoh kesalahan penulisan huruf kapital adalah sebagai berikut. 


\begin{tabular}{|l|l|}
\hline AP/II \& 4 & $\begin{array}{l}\text { menyimak bermakna mendengarkan dengan penuh } \\
\text { pemahaman ... }\end{array}$ \\
\hline
\end{tabular}

\begin{tabular}{|l|l|}
\hline BP/II \& 19 & $\begin{array}{l}\ldots \text { anda perlu berkonsentrasi terhadap apa yang anda } \\
\text { simak. }\end{array}$ \\
\hline
\end{tabular}

Pada kalimat AP/II \& 4 terdapat kesalahan dalam penggunaan huruf kapital. Kesalahan terebut terdapat pada kata menyimak. Kata menyimak diawali dengan huruf kecil itu tidak benar, karena kata menyimak letaknya terdapat di awal kalimat. Seharusnya kata menyimak huruf pertamanya menggunakan huruf kapital karena huruf kapital dipakai sebagai huruf pertama awal kalimat. Dengan demikian, bentuk kalimat AP/II \& 4 yang benar adalah sebagai berikut.

\begin{tabular}{|l|l|}
\hline AP/II \& 4a & $\begin{array}{l}\text { Menyimak bermakna mendengarkan dengan penuh } \\
\text { pemahaman ... }\end{array}$ \\
\hline
\end{tabular}

Kalimat BP/II \& 19 juga mengandung kesalahan dalam penggunaan huruf kapital yaitu pada kata anda. Kata anda pada kalimat tersebut harusnya huruf pertamanya menggunakan huruf kapital, seperti yang tertera dalam Pedoman Umum Ejaan Bahasa Indonesia (2005) bahwa kata ganti Anda harus ditulis awal kapital.

Selain kesalahan penggunaan huruf kapital, terdapat juga beberapa kesalahan penggunaan huruf miring. Berikut beberapa contoh kesalahan huruf miring yang terdapat pada artikel ilmiah mahasiswa.

\begin{tabular}{|l|l|}
\hline $\mathrm{AP} / \mathrm{KI} \& 5$ & $\begin{array}{l}\text { sebuah buku petunjuk mengenai keterampilan } \\
\text { berbahasa yang berjudul "Tulare Coutry } \\
\text { Cooperative Language Arts Guide". }\end{array}$ \\
\hline
\end{tabular}

\begin{tabular}{|l|l|}
\hline AP/II \& 10 & Konteks sosial mempunyai kelas sosial (social class) \\
\hline
\end{tabular}

Kesalahan penulisan huruf miring terdapat pada kalimat AP/II \& 5 . Kalimat yang bercetak tebal tersebut harusnya ditulis miring seperti yang tertera dalam Pedoman Umum Ejaan Bahasa Indonesia (2015) bahwa huruf miring 
dipakai untuk menuliskan, judul buku, nama majalah, atau nama surat kabar yang dikutip dalam tulisan, termasuk dalam daftar pustaka. Dengan demikian, bentuk kalimat $\mathrm{AP} / \mathrm{II} \& 5$ yang benar adalah sebagai berikut.

\begin{tabular}{|l|l|}
\hline AP/II \& 5a & $\begin{array}{l}\text {. sebuah buku petunjuk mengenai keterampilan } \\
\text { berbahasa yang berjudul "Tulare Coutry Cooperative } \\
\text { Language Arts Guide". }\end{array}$ \\
\hline
\end{tabular}

Kesalahan penulisan huruf miring pada kalimat AP/II \& 5 tersebut, terdapat juga kesalahan penulisan huruf miring pada kalimat AP/II \& 10. Pada kata yang bercetak tebal harusnya ditulis miring, seperti yang tertera pada Pedoman Umum Ejaan Bahasa Indonesia (2015) bahwa huruf miring dipakai untuk menuliskan kata atau ungkapan dalam bahasa daerah atau bahasa asing. Dengan demikian bentuk kalimat AP/II 10 yang benar adalah sebagai berikut.

\begin{tabular}{|l|l|l|l|l}
\hline AP/II \& 10a & Konteks sosial mempunyai kelas sosial (social class)
\end{tabular}

\section{b. Penulisan Kata}

Peneliti menemukan beberapa kesalahan dalam penulisan kata, yaitu dalam penulisan kata depan di-. Berikut beberapa contoh kesalahan dalam penulisan kata depan yang peneliti temukan.

\begin{tabular}{|l|l|}
\hline AP/K1 \& 9 & $\begin{array}{l}\text {.. petunjuk-petunjuk lisan yang di sampaikan dengan } \\
\text { jelas. }\end{array}$ \\
\hline
\end{tabular}

\begin{tabular}{|l|l|}
\hline AP/II \& 9 & Sebagian atau semua faktor tersebut diatas ... \\
\hline
\end{tabular}

Kesalahan dalam penulisan kata depan $d i$ - yang terdapat pada dua kalimat di atas tidak tepat penulisannya, karena pada buku Pedoman Umum Ejaan Bahasa Indonesia (2015) kata depan, seperti di, ke, dan dari, ditulis terpisah dari kata yang mengikutinya. Dengan demikian, kata di sampaikan pada kalimat $\mathrm{AP} / \mathrm{KI} \& 9$ ditulis serangkai karena kata di- bukan merupakan kata depan. Sedangkan kata diatas pada kalimat AP/II \& 9 ditulis terpisah karena kata $d i$ - pada kalimat tersebut merupakan kata depan, berikut perbaikannya. 


\begin{tabular}{|l|l|}
\hline AP/K1 \& 9a & $\begin{array}{l}\text { f petunjuk-petunjuk lisan yang disampaikan dengan } \\
\text { jelas. }\end{array}$ \\
\hline
\end{tabular}

\begin{tabular}{l|l}
\hline $\mathrm{AP} / \mathrm{II} \&$ 9a & Sebagian atau semua faktor tersebut di atas ...
\end{tabular}

\section{c. Pemakaian Tanda Baca}

Berikut data kalimat yang terdapat kesalahan penggunaan tanda baca petik.

\begin{tabular}{|l|l|}
\hline $\mathrm{CP} / \mathrm{K} 2 \& 3$ & ..oleh si pembicara melalui ujaran atau bahasa lisan ". \\
\hline
\end{tabular}

Seperti penjelasan yang terdapat pada Pedoman Umum Ejaan Bahasa Indonesia (2015) bahwa tanda petik dipakai untuk mengapit petikan langsung yang berasal dari pembicaraan, naskah, atau bahan tertulis lain. Dengan demikian, tanda petik pada kalimat di atas tidak perlu digunakan karena tidak ada petikan langsung pada kalimat tersebut.

\begin{tabular}{|l|l}
\hline $\mathrm{CP} / \mathrm{K} 2 \& 3 \mathrm{a}$ & ..oleh si pembicara melalui ujaran atau bahasa lisan .
\end{tabular}

\section{d. Penulisan Unsur Serapan}

Berikut beberapa contoh kesalahan dalam penulisan unsur serapan pada artikel ilmiah mahasiswa.

\begin{tabular}{|l|l}
\hline DP/K1\&10 & Menyimak informative...menyimak literature
\end{tabular}

Pada kalimat di atas mengandung kesalahan dalam penulisan unsur serapan. Kata informative dan literature sudah diserap ke dalam bahasa Indonesia menjadi informatif dan literatur. Dengan demikian, bentuk kalimat di atas yang benar adalah sebagai berikut.

\begin{tabular}{|l|l}
\hline $\mathrm{DP} / \mathrm{K} 1 \& 10 \mathrm{a}$ & Menyimak informatif...menyimak literatur
\end{tabular}


2. Sistematika Penulisan Artikel Ilmiah Mahasiswa Program Studi Pendidikan Bahasa dan Sastra Indonesia Angkatan 2017 IKIP PGRI Pontianak

\section{a. Penulisan Judul}

Penulisaan judul pada artikel ilmiah mahasiswa Program Studi Pendidikan Bahasa dan Sastra Indonesia Angkatan 2017 IKIP PGRI Pontianak terdapat 4 kesalahan penulisan. Analisis dilakukan dengan memperhatikan syarat penulisan judul yang baik meliputi 5 komponen; 1. Informatif mencerminkan isi artikel, 2. Tidak terlalu pendek dan tidak terlalu panjang (kira-kira 5 s.d. 14 kata), 3. Memuat variable atau konsep yang dicakup dalam artikel, 4. Tidak ada singkatan, 5. Tidak menggunakan katakata klise, Suwandi (2012:83).

Dua tipe kesalahan dalam penulisan judul yaitu: a. tidak mencantumkan judul dan b. judul yang ditulis terlalu singkat dan kurang informatif. Berikut contoh kesalahan yang dimaksud.

\begin{tabular}{|l|l}
\hline K1.DP & penulis tidak mencantumkan judul penelitian
\end{tabular}

Data kelompok 1 di kelas D Pagi, menunjukkan bahwa penulis tidak mencantumkan judul penelitian. Penulis seharusnya mencantumkan judul penelitian dengan memperhatikan syarat judul yang baik; 1. Informatif mencerminkan isi artikel, 2. Tidak terlalu pendek dan tidak terlalu panjang (kira-kira 5 s.d. 14 kata), 3. Memuat variabel atau konsep yang dicakup dalam artikel, 4. Tidak ada singkatan, 5. Tidak menggunakan kata-kata klise.

\begin{tabular}{|l|l}
\hline K3.CP & "Pendekatan dan Teknik-teknik Menyimak"
\end{tabular}

Data kelompok 3 kelas C Pagi penulis sudah mencantumkan judul artikel ilmiah, tetapi masih terlalu singkat dan kurang informatif. Seharusnya judul ditulis tidak terlalu singkat sekitar 5 sampai 14 kata dan mencerminkan isi artikel. Judul yang terlalu singkat cendrung tidak fokus pada satu permasalahan, sehingga sebagai penulis hendaknya memikirkan 
judul dan istilah yang digunakan dalam menulis judul harus fokus pada satu objek kajian dan tidak mengandung singkatan serta kata-kata klise

\section{b. Penulisan Nama Penulis}

Analisis penulisaan nama penulis pada artikel ilmiah mahasiswa Program Studi Pendidikan Bahasa dan Sastra Indonesia Angkatan 2017 IKIP PGRI Pontianak tidak terdapat kesalahan penulisan. Analisis dilakukan dengan memperhatikan syarat penulisan mengacu pada pendapat Suwandi, (2012:83) "Guna menghindari bias terhadap senioritas dan wibawa, nama penulis artikel ilmiah hendaknya tanpa disertai gelar akademik, cukup mencantumkan lembaga tempat bekerja.

\section{c. Penulisan Abstrak dan Kata Kunci}

Analisis penulisaan abstrak dan kata kunci pada artikel ilmiah mahasiswa Program Studi Pendidikan Bahasa dan Sastra Indonesia Angkatan 2017 IKIP PGRI Pontianak terdapat 12 kesalahan penulisan (semua artikel ilmiah yang dianalisis tidak mencantumkan abstrak dan kata kunci). Abstrak ditulis ringkas dan padat, ditulis dalam satu paragraf. Menurut Suwandi (2012:83-84) abstrak memuat; 1. Masalah dan/atau tujuan penelitian, 2. Prosedur penelitian. 3. Ringkasan hasil penelitian. 4 simpulan, dan memuat kata kunci 3-5.

Seharusnya artikel ilmiah memuat abstrak dan kata kunci dengan tujuan untuk mempermudah pembaca memahami isi artikel. Tujuan penulisan abstrak adalah untuk menangkap isi dokumen yang esensial sehingga dalam waktu singkat pembaca dapat mengetahui informasi yang terkandung dalam dokumen.

\section{d. Penulisan Pendahuluan}

Analisis penulisaan bagian pendahuluan pada artikel ilmiah mahasiswa Program Studi Pendidikan Bahasa dan Sastra Indonesia Angkatan 2017 IKIP PGRI Pontianak terdapat 9 kesalahan penulisan. Analisis dilakukan dengan memperhatikan syarat penulisan pendahuluan yang baik meliputi 5 komponen; 1. latar belakang atau konteks penelitian, 2. landasan teori (jika diperlukan). 3 hasil kajian pustaka yang menunjukan adanya 
kesenjangan temuan penelitian. 4. wawasan rencana pemecahan masalah, dan 5. rumusan tujuan penelitian, Suwandi (2012:83-84).

Terdapat 2 tipe kesalahan dalam penulisan pendahuluan yaitu: a. artikel ilmiah yang memuat latar belakang tetapi tidak sesuai dengan permasalahan atau konteks penelitian, ditemukan sebanyak 3 artikel ilmiah, b. artikel ilmiah dengan tipe kesalahan tidak memuat latar belakang atau konteks penelitian tidak jelas dan tidak memuat hasil kajian pustaka yang menunjukkan adanya kesenjangan temuan penelitian pada latar belakang, ditemukan sebanyak 6 artikel ilmiah.

\section{e. Penulisan Bagian Inti (Hasil dan Pembahasan)}

Penulisaan bagian inti (hasil dan pembahasan) artikel ilmiah mahasiswa Program Studi Pendidikan Bahasa dan Sastra Indonesia Angkatan 2017 IKIP PGRI Pontianak terdapat 8 kesalahan penulisan. Analisis dilakukan dengan memperhatikan syarat penulisan hasil dan pembahasan yang baik meliputi 4 komponen; 1. jawaban masalah atau menunjukan bagaimana tujuan penelitian dicapai, 2. penafsiran hasil-hasil penelitian, 3 . pengintegrasian hasil-hasil penelitian ke dalam kumpulan pengetahuan yang telah mapan, 4. menyusun teori baru atau memodifikasi teori yang ada, Suwandi (2012:83-84).

Terdapat 4 tipe kesalahan dalam penulisan bagian inti (hasil dan pembahasan) yaitu: Pertama, artikel ilmiah yang tidak memuat komponen 1 . jawaban masalah atau menunjukan bagaimana tujuan penelitian dicapai, 2 . penafsiran hasil-hasil penelitian, 3. pengintegrasian hasil-hasil penelitian ke dalam kumpulan pengetahuan yang telah mapan, sebanyak 2 artikel. Kedua, artikel ilmiah yang tidak memuat komponen 1. jawaban masalah atau menunjukan bagaimana tujuan penelitian dicapai, 2. penafsiran hasil-hasil penelitian, sebaanyak 2 artikel. Ketiga, artikel ilmiah yang tidak memuat komponen 1. jawaban masalah atau menunjukan bagaimana tujuan penelitian dicapai, sebanyak 1 artikel. Keempat, artikel ilmiah yang tidak memuat komponen 2. penafsiran hasil-hasil penelitian, sebanyak 3 artikel.) 


\section{f. Penulisan Bagian Penutup (Simpulan)}

Penulisaan bagian penutup (simpulan) pada artikel ilmiah mahasiswa Program Studi Pendidikan Bahasa dan Sastra Indonesia Angkatan 2017 IKIP PGRI Pontianak terdapat 9 kesalahan penulisan. Analisis dilakukan dengan memperhatikan syarat penulisan simpulan, 1. simpulan memuat jawaban atas pertanyaan penelitian dalam bentuk substantif (esai), 2. memuat implikasi temuan penelitian, 3. memuat saran yang mengacu pada tindakan praktis atau pengembangan teori dan penelitian lanjutan, Suwandi (2012:83-86).

Terdapat 5 tipe kesalahan dalam penulisan bagian penutup (simpulan) yaitu: Pertama, artikel ilmiah yang tidak memuat komponen 1. simpulan memuat jawaban atas pertanyaan penelitian dalam bentuk substantif (esai), 2 . memuat implikasi temuan penelitian, sebanyak 1 artikel. Kedua, artikel ilmiah yang tidak memuat komponen 1. simpulan memuat jawaban atas pertanyaan penelitian dalam bentuk substantif (esai), dan 3. memuat saran yang mengacu pada tindakan praktis atau pengembangan teori dan penelitian lanjutan, sebanyak 1 artikel. Ketiga, artikel ilmiah yang tidak memuat komponen 1. simpulan memuat jawaban atas pertanyaan penelitian dalam bentuk substantif (esai), sebanyak 5 artikel. Keempat, artikel ilmiah yang tidak memuat komponen 2. memuat implikasi temuan penelitian, sebanyak 1 artikel. Kelima, artikel ilmiah yang tidak memuat komponen 3. memuat saran yang mengacu pada tindakan praktis atau pengembangan teori dan penelitian lanjutan, sebanyak 1 artikel.

\section{g. Penulisan Daftar Rujukan}

Penulisaan bagian daftar rujukan pada artikel ilmiah mahasiswa Program Studi Pendidikan Bahasa dan Sastra Indonesia Angkatan 2017 IKIP PGRI Pontianak terdapat 9 kesalahan penulisan. Analisis dilakukan dengan memperhatikan syarat penulisan daftar rujukan. Terdapat dua persayaratan dalam menulis daftar rujukan, Suwandi (2012:83-86) syarat pertama yaitu daftar rujukan hanya memuat daftar referensi yang digunakan di dalam artikel ilmiah dan syarat kedua yaitu artikel ilmiah disusun berdasarkan urutan abjad. 
Terdapat 2 tipe kesalahan dalam penulisan bagian daftar rujukan yaitu: Pertama, artikel ilmiah yang tidak mencantumkan daftar referensi yang digunakan di dalam artikel ilmiah atau daftar referensi tidak sesuai,ditemukan sebanyak 8 artikel. Kedua, artikel ilmiah yang menyusun daftar rujukan tidak sesuai denegan urutan abjad, ditemukan 1 artikel.

\section{SIMPULAN}

Berdasarkan rumusan masalah dan tujuan yang peneliti sampaikan sebelumnya, serta hasil analisis yang telah peneliti jabarkan pada bab sebelumnya, maka dikemukakan simpulan umum penelitian ini adalah penggunaan bahasa Indonesia dalam penulisan artikel ilmiah pada mahasiswa Program Studi Pendidikan Bahasa dan Sastra Indonesia tergolong sedang. Simpulan tersebut dipersempit menjadi beberapa sub, sebagai berikut:

1. Kesalahan ejaan pada artikel ilmiah mahasiswa Program Studi Pendidikan Bahasa dan Sastra Indonesia angkatan 2017 IKIP PGRI Pontianak tergolong kurang efektif. Kesalahan penggunaaan ejaan tersebut hampir setiap artikel ilmiah yang ditulis mahasiswa. Kesalahan meliputi beberapa aspek diantaranya; (a) kesalahan pemakaian pemakaian huruf berjumlah 20 kesalahan. Kesalahan tersebut terdapat pada penggunaan huruf miring dan penggunaan huruf kapital, (b) kesalahan penulisan kata 44 kesalahan. Kesalahan tersebut terdapat pada penggunaan kata depan (c) kesalahan pemakaian tanda baca berjumlah 2 kasus kesalahan yaitu kesalahan pada penggunaan tanda petik serta pada tanda koma, dan (d) kesalahan penulisan unsur serapan 10 kesalahan.

2. Kesalahan di bidang sistematika penulisan artikel ilmiah berupa; a. kesalahan dalam penulisan judul sebanyak 4 kasus kesalahan (artikel tidak mencantumkan judul dan judul yang ditulis terlalu singkat dan kurang informatif), b. kesalahan dalam mencantumkan nama penulis (tidak ditemukan kesalahan) c. kesalahan dalam menulis abstrak dan kata kunci sebanyak 12 kesalahan, (semua artikel tidak mencantumkan abstrak dan kata kunci) d. kesalahan dalam menulis bagian pendahuluan dalam artikel ilmiah ditemukan sebanyak 9 kesalahan (artikel ilmiah yang 
memuat latar belakang tetapi tidak sesuai dengan permasalahan atau konteks penelitian, dan artikel ilmiah dengan tipe kesalahan tidak memuat latar belakang atau konteks penelitian tidak jelas dan tidak memuat hasil kajian pustaka yang menunjukkan adanya kesenjangan temuan penelitian pada latar belakang, e. kesalahan dalam menuliskan bagian inti (hasil dan pembahasan) ditemukan sebanyak 7 kesalahan, (artikel ilmiah yang tidak memuat jawaban masalah atau menunjukan bagaimana tujuan penelitian dicapai, penafsiran hasil-hasil penelitian, dan pengintegrasian hasil-hasil penelitian ke dalam kumpulan pengetahuan yang telah mapan $f$. kesalahan dalam menuliskan bagian penutup (simpulan) ditemukan sebanyak 9 kesalahan, (simpulan tidak memuat jawaban atas pertanyaan penelitian dalam bentuk substantif dan simpulan tidak memuat implikasi temuan penelitian dan g. kesalahan dalam penulisan daftar rujukan ditemukan sebanyak 9 kesalahan (artikel ilmiah yang tidak mencantumkan daftar referensi yang digunakan di dalam artikel ilmiah atau daftar referensi tidak sesuai, dan artikel ilmiah yang menyusun daftar rujukan tidak sesuai dengan urutan abjad)

\section{DAFTAR PUSTAKA}

Alwi, H. (2011). Bahasa Indonesia Pemakai dan Pemakaiannya. Jakarta: Badan Pengembangan dan Pembinaan Bahasa Kemendikbud.Aslinda dan Syafyahya, L. (2014). Pengantar Sosiolinguistik. Bandung: PT Refika Aditama.

Apandi, I. (2015). Saya Guru Saya Bisa Menulis Panduan Menulis Artikel Ilmiah Populer dan Artikel Jurnal Ilmiah Bagi Guru. Bandung: CV. SMILE's Indonesia Institue.

Ayudia, dkk. (2016). Analisis Kesalahan Penggunaan Bahasa ndonesia dalam Laporan Hasil Observasi pada Siswa SMP. BASASTRA Jurnal Penelitian Bahasa, Sastra Indonesia dan Pengajarannya. 4 (1): 34-49.

Barnawi, \& Arifin, M. (2015). Teknik Penulisan Karya Ilmiah. Jogjakarta: ArRuzz Media.

Budiharso, T. (2009). Panduan Lengkap Penulisan Karya Ilmiah. Yogyakarta: Venus.

Chaer, A. (2011). Tata Bahasa Praktis Bahasa Indonesia. Jakarta: Rineka Cipta. 
Fatihudin, D \& Holisin, I. (2011). Cara Praktis Memahami Penulisan Karya Ilmiah, Artikel Ilmiah, \& Hasil Penelitian Skripsi, Tesis, dan Desertasi. Yogyakarta: sekolah tinggi ilmu manajemen YKPN.

Hazma, W \& Kurning P. (2017). Peran Bahasa Indonesia dalam Meningkatkan Kualitas Jurnal di Polban. Sigma-Mu. 9 (1): 66-81.

Mahsun. (2012). Metode Penelitian Bahasa Tahapan Strategi, Metode, dan Tekniknya. Jakarta: PT RajaGrafindo Persada.

Soeharso. (2009). Teknik, Nulis Artikel Buku Panduan untuk Siapa Saja yang Ingin Belajar Menulis Artikel Ilmiah Popular di Media Massa. Semarang: karya aksara.

Soeseno. (1982). Teknik Penulisan Ilmiah-Populer. Jakarta: Gramedia.

Sultan. (2013). Penggunaan Kalimat dalam Artikel Ilmiah Hasil Penelitian. Jurnal Penelitian Pendidikan INSANI. 14 (1): 33-38.

Sutopo, H.B. (2002). Metode Penelitian Kualitatif Dasar Teori dan Terapannya dalam Penelitian. Surakarta: UNS Press. 